\title{
Using the Robson classification to assess caesarean section rates in Brazil: an observational study of more than 24 million births from 2011 to 2017
}

Enny S. Paixao ${ }^{1,2^{*}}$, Christian Bottomley ${ }^{1}$, Liam Smeeth ${ }^{1}$, Maria Conceicao N. da Costa ${ }^{2,3}$, Maria Gloria Teixeira ${ }^{2,3}$, Maria Yury Ichihara ${ }^{2}$, Ligia Gabrielli', Mauricio L. Barreto ${ }^{2}$ and Oona M. R. Campbell ${ }^{1}$

\begin{abstract}
Background: Applying the Robson classification to all births in Brazil, the objectives of our study were to estimate the rates of caesarean section delivery, assess the extent to which caesarean sections were clinically indicated, and identify variation across socioeconomic groups.

Methods: We conducted a population-based study using routine records of the Live Births Information System in Brazil from January 1, 2011, to December 31, 2017. We calculated the relative size of each Robson group; the caesarean section rate; and the contribution to the overall caesarean section rate. We categorised Brazilian municipalities using the Human Development Index to explore caesarean section rates further. We estimated the time trend in caesarean section rates.

Results: The rate of caesarean sections was higher in older and more educated women. Prelabour caesarean sections accounted for more than $54 \%$ of all caesarean deliveries. Women with a previous caesarean section (Group 5) made up the largest group (21.7\%). Groups 6-9, for whom caesarean sections would be indicated in most cases, all had caesarean section rates above $82 \%$, as did Group 5 . The caesarean section rates were higher in municipalities with a higher HDI. The general Brazilian caesarean section rate remained stable during the study period.
\end{abstract}

Conclusions: Brazil is a country with one of the world's highest caesarean section rates. This nationwide population-based study provides the evidence needed to inform efforts to improve the provision of clinically indicated caesarean sections. Our results showed that caesarean section rates were lower among lower socioeconomic groups even when clinically indicated, suggesting sub-optimal access to surgical care.

Keywords: Robson classification, Caesarean section rates, Brazil, Mode of delivery

\footnotetext{
* Correspondence: enny.cruz@lshtm.ac.uk

${ }^{1}$ Faculty of Epidemiology and Population Health, London School of Hygiene and Tropical Medicine, London, United Kingdom

${ }^{2}$ Centro de Integração de Dados e Conhecimentos para Saúde, Fiocruz, Salvador, Bahia, Brazil

Full list of author information is available at the end of the article
}

(c) The Author(s). 2021 Open Access This article is licensed under a Creative Commons Attribution 4.0 International License, which permits use, sharing, adaptation, distribution and reproduction in any medium or format, as long as you give appropriate credit to the original author(s) and the source, provide a link to the Creative Commons licence, and indicate if changes were made. The images or other third party material in this article are included in the article's Creative Commons licence, unless indicated otherwise in a credit line to the material. If material is not included in the article's Creative Commons licence and your intended use is not permitted by statutory regulation or exceeds the permitted use, you will need to obtain permission directly from the copyright holder. To view a copy of this licence, visit http://creativecommons.org/licenses/by/4.0/ The Creative Commons Public Domain Dedication waiver (http://creativecommons.org/publicdomain/zero/1.0/) applies to the data made available in this article, unless otherwise stated in a credit line to the data. 


\section{Background}

An ideal rate of caesarean sections has not been agreed, however, the progressive increase in caesarean section deliveries has intensified debate over the procedure in the last decade [1-3]. Although a caesarean section can be life-saving, it can also pose unnecessary risks to mothers and babies [4]. In the absence of a clear medical indication, the benefits of a caesarean section remain uncertain.

Identifying an unindicated caesarean section for any given woman or foetus is problematic, not least because financial incentives may encourage health systems and providers to use "soft" indications that are difficult to challenge. To address this problem, the Robson classification system has been used to group women into one of ten mutually-exclusive categories, based on six essential obstetric characteristics [5], namely: parity, previous caesarean section, gestational age, the onset of labour, foetal presentation, and number of fetuses [5]. An additional category comprises women who could not be classified because of missing or contradictory information. This instrument has been used worldwide to reduce the rates of unnecessary caesarean sections and improve obstetric care, and is indicated by $\mathrm{WHO}$ as a monitoring tool [6].

In Brazil, the Robson classification system has been previously applied in the national "Birth in Brazil" cohort [7], and some hospital-based studies in Sao Paulo [8] and Brasilia [9]. Using routinely collected birth registration data, the objectives of our study were to (1) estimate the caesarean rate in Brazil stratified by Robson category, (2) assess the extent to which caesarean sections were clinically indicated, and (3) identify any variation across different socioeconomic groups.

\section{Methods}

We conducted a population-based study using routine records of the Live Births Information System (Sistema de Informação sobre Nascimentos; SINASC) in Brazil from January 1, 2011 to December 31, 2017. SINASC records all registered live births in Brazil using a standardised form that is completed by a health professional who attended the delivery. The Brazilian Ministry of Health maintains the data, and an evaluation of the birth registration system found that over $97 \%$ of Brazilian live births were registered [10]. The form includes information on the mother (name, place of residence, age, marital status, education); the pregnancy (length of gestation, mode of delivery); and the neonate (birth weight, presence of congenital anomalies) [11]. In 2011, the form was amended to include information about the father, birth conditions, and obstetric history [12].

Because the SINASC form does not have information on previous births, we used the number of previous pregnancies as a proxy for parity. We also subdivided Robson Groups 2 and 4 into $2 \mathrm{a}$ and $2 \mathrm{~b}$ and $4 \mathrm{a}$ and $4 \mathrm{~b}$ to distinguish women with induced labour from those with a pre-labour caesarean section.

We estimated the rate of caesarean section stratified by maternal age $(<20,20-24,25-29,30-34,35-39,40-$ 44 , and $>45$ years), maternal education (illiterate, 1-3 years, 4-7 years, 8-11 years and more than 12 years), maternal marital status (single, widow, divorced, married), gestational age $(20-21,22-23,24-25,26-27,28-$ $29,30-31,32-33,34-35,36-37,38-39,40-41,>42$ weeks), birth weight $(<1,500,1500-1999,2000-2499$, 2500-2999, 3000-3499, 3500-3999, > 4000 g), number of foetuses, delivery presentation, onset of labour, previous gestations and previous caesarean sections.

As recommended by WHO [13], we calculated the proportion of deliveries in each Robson group, the proportion of deliveries in each group that were by caesarean section, and the contribution of each group to the overall caesarean section rate (number of caesarean deliveries divided by the total number of births).

To further explore caesarean section rates within each Robson Group, we categorised Brazilian municipalities as having a very high, high, medium, or low Human Development Index (HDI), based on the 2010 Human Development Report [14], and estimated caesarean section rates stratified by HDI category.

Finally, we estimated the time trend $(\beta$ coefficient which corresponds to the change in the caesarean section rate for every year) in caesarean section rates for each Robson group using either simple linear regression or the Prais-Winsten method if there was evidence of autocorrelation (Durbin-Watson statistic > 2) [15].

\section{Results}

The Live Births Information System (SINASC) recorded 20,462,786 live births in Brazil between 2011 and 2017, $55.7 \%(n=11,405,901)$ of which were delivered by caesarean section. The characteristics of these births are shown in Table 1. The rate of caesarean sections was higher in older and more educated women, and increased with gestational age with a peak at 36-39 weeks (60\%). Prelabour caesarean sections accounted for more than $54 \%$ of all caesarean deliveries.

A total of 15,426,356 (75.4\%) records had information on all six core variables required for the Robson classification. Women with a previous caesarean section was the largest group (Group 5, $21.7 \%$ ), followed by primigravidae women with a single cephalic pregnancy at 37 + weeks gestation in spontaneous labour (Group 1, $16.1 \%$ ) and primigravidae women who had labour induced or had a prelabour caesarean section (Group 2, $17.2 \%$ ) (Table 2). 
Table. 1 Characteristics of 20,462,786 live births in Brazil from 2011-2017 by mode of delivery

\begin{tabular}{|c|c|c|c|c|}
\hline Characteristics & Vaginal Births & Caesarean section births & Total births & Caesarean section rate (\%) \\
\hline \multicolumn{5}{|c|}{ Age of the mother } \\
\hline$<20$ years & $2,257,865$ & $1,507,565$ & $3,765,430$ & 40.0 \\
\hline $20-24$ & $2,651,696$ & $2,561,203$ & $5,212,899$ & 49.1 \\
\hline $25-29$ & $2,029,296$ & $2,934,567$ & $4,963,863$ & 59.1 \\
\hline $30-34$ & $1,334,853$ & $2,647,268$ & $3,982,121$ & 66.5 \\
\hline $35-39$ & 619,443 & $1,403,459$ & $2,022,902$ & 69.4 \\
\hline $40-44$ & 152,084 & 330,638 & 482,722 & 68.5 \\
\hline$\geq 45$ years & 11,486 & 21,198 & 32,684 & 64.9 \\
\hline Missing & 162 & 3 & 165 & \\
\hline \multicolumn{5}{|c|}{ Marital status of the mother } \\
\hline Single & $4,473,028$ & $4,205,309$ & $8,678,337$ & 48.5 \\
\hline Widow & 15,747 & 22,160 & 37,907 & 58.5 \\
\hline Divorced & 69,084 & 151,019 & 220,103 & 68.6 \\
\hline Married/union & $4,377,696$ & $6,903,721$ & $11,281,417$ & 61.2 \\
\hline Missing & 121,330 & 123,692 & 245,022 & \\
\hline \multicolumn{5}{|c|}{ Maternal education } \\
\hline None & 101,362 & 36,223 & 137,585 & 26.3 \\
\hline $1-3$ years & 453,747 & 255,239 & 708,986 & 36.0 \\
\hline $4-7$ years & $2,413,955$ & $1,712,643$ & $4,126,598$ & 41.5 \\
\hline $8-12$ years & $5,236,732$ & $6,339,551$ & $11,576,283$ & 54.8 \\
\hline$\geq 12$ years & 683,137 & $2,879,121$ & $3,562,258$ & 80.8 \\
\hline Missing & 167,952 & 183,124 & 351,076 & \\
\hline \multicolumn{5}{|l|}{ Birth weight (g) } \\
\hline$<1500$ & 119,571 & 151,935 & 271,506 & 56.0 \\
\hline 1500-1999 & 116,372 & 205,613 & 321,985 & 63.9 \\
\hline $2000-2499$ & 504,704 & 630,673 & $1,135,377$ & 55.5 \\
\hline 2500-2999 & $2,233,728$ & $2,465,243$ & $4,698,971$ & 52.5 \\
\hline 3000-3499 & $3,838,057$ & $4,666,113$ & $8,504,170$ & 54.9 \\
\hline 3500-3999 & $1,868,805$ & $2,609,963$ & $4,478,768$ & 58.3 \\
\hline$>=4000$ & 361,960 & 674,268 & $1,036,228$ & 65.1 \\
\hline Missing & 13,688 & 2,093 & 15,781 & \\
\hline \multicolumn{5}{|c|}{ Number of babies } \\
\hline Singleton & $8,971,608$ & $11,046,099$ & $20,017,707$ & 55.2 \\
\hline Twins or more & 73,725 & 346,756 & 420,481 & 82.5 \\
\hline Missing & 11,552 & 13,046 & 24,598 & \\
\hline \multicolumn{5}{|c|}{ Gestational age at delivery (weeks) } \\
\hline $20-21$ & 7,802 & 2,049 & 9,851 & 20.8 \\
\hline $22-23$ & 14,238 & 3,382 & 17,620 & 19.2 \\
\hline $24-25$ & 20,210 & 9,629 & 29,839 & 32.3 \\
\hline $26-27$ & 24,005 & 21,720 & 45,725 & 47.5 \\
\hline $28-29$ & 31,288 & 38,382 & 69,670 & 55.1 \\
\hline $30-31$ & 56,592 & 71,165 & 127,757 & 55.7 \\
\hline $32-33$ & 133,450 & 164,768 & 298,218 & 55.3 \\
\hline $34-35$ & 338,158 & 416,552 & 754,710 & 55.2 \\
\hline
\end{tabular}


Table. 1 Characteristics of 20,462,786 live births in Brazil from 2011-2017 by mode of delivery (Continued)

\begin{tabular}{|c|c|c|c|c|}
\hline Characteristics & Vaginal Births & Caesarean section births & Total births & Caesarean section rate (\%) \\
\hline $36-37$ & $1,006,292$ & $1,496,184$ & $2,502,476$ & 59.8 \\
\hline $38-39$ & $3,632,480$ & $5,441,531$ & $9,074,011$ & 60.0 \\
\hline $40-41$ & $2,553,334$ & $2,367,207$ & $4,920,541$ & 48.1 \\
\hline$>42$ & 327,221 & 303,210 & 630,431 & 48.1 \\
\hline Missing & 911,815 & $1,070,122$ & $1,981,937$ & \\
\hline \multicolumn{5}{|l|}{ Delivery Year } \\
\hline 2011 & $1,340,324$ & $1,565,564$ & $2,905,888$ & 53.9 \\
\hline 2012 & $1,283,546$ & $1,615,928$ & $2,899,474$ & 55.7 \\
\hline 2013 & $1,253,726$ & $1,644,557$ & $2,898,283$ & 56.7 \\
\hline 2014 & $1,277,175$ & $1,697,954$ & $2,975,129$ & 57.1 \\
\hline 2015 & $1,336,952$ & $1,672,150$ & $3,009,102$ & 55.6 \\
\hline 2016 & $1,272,867$ & $1,583,667$ & $2,856,534$ & 55.4 \\
\hline 2017 & $1,292,295$ & $1,626,081$ & $2,918,376$ & 55.7 \\
\hline \multicolumn{5}{|l|}{ Delivery presentation } \\
\hline Cephalic & $8,238,500$ & $9,562,522$ & $17,801,022$ & 53.7 \\
\hline Breech & 92,719 & 620,941 & 713,660 & 87.0 \\
\hline Transverse & 1,622 & 47,792 & 49,414 & 96.7 \\
\hline Missing & 724,044 & $1,174,646$ & $1,898,690$ & \\
\hline \multicolumn{5}{|l|}{ Induced labour } \\
\hline Yes & $2,465,297$ & 941,135 & $3,406,432$ & 27.6 \\
\hline No & $5,555,713$ & $8,975,386$ & $14,531,099$ & 61.8 \\
\hline Missing & $1,035,875$ & $1,489,380$ & $2,525,255$ & \\
\hline \multicolumn{5}{|l|}{ Prelabour caesarean } \\
\hline Yes & 0 & $5,087,474$ & $5,087,474$ & 100.0 \\
\hline No & 0 & $4,375,777$ & $4,375,777$ & 100.0 \\
\hline Not applicable (no caesarean) & $7,781,452$ & 69,172 & $7,850,624$ & 0.9 \\
\hline Missing & $1,275,433$ & $1,873,478$ & $3,148,911$ & \\
\hline \multicolumn{5}{|c|}{ Previous pregnancy and caesarean section } \\
\hline No previous pregnancy & $3,033,741$ & $4,391,353$ & $7,425,094$ & 59.1 \\
\hline Previous caesarean delivery & 637,171 & $3,933,237$ & $4,570,408$ & 86.1 \\
\hline No previous caesarean delivery & $4,130,500$ & $1,856,212$ & $5,986,712$ & 31.0 \\
\hline Missing & $1,225,099$ & $1,255,473$ & $2,480,572$ & \\
\hline \multicolumn{5}{|l|}{ HID } \\
\hline Very High & $1,667,342$ & $2,402,466$ & $4,069,808$ & 59.0 \\
\hline High & $4,503,476$ & $6,801,017$ & $11,304,493$ & 60.2 \\
\hline Medium & $2,599,014$ & $2,120,271$ & $4,719,285$ & 44.9 \\
\hline Low & 287,009 & 82,147 & 369,156 & 22.3 \\
\hline
\end{tabular}

NA not applicable

*For women with a caesarean, these are not applicable for other, poorly defined reasons

Groups 6-9 (breeches, multiple pregnancies, and transverse/oblique lies), for whom caesarean sections would be indicated in most cases, all had caesarean section rates above $80 \%$, as did women who had had a previous caesarean (Group 5). Primigravid women at term, singleton, and cephalic pregnancy in spontaneous labour
(Group1) were almost twice as likely to deliver by caesarean section as those with induced labour (Group 2a) $(43.8 \%$ vs. $24.0 \%)$. Women with a previous caesarean section and primigravid women accounted for twothirds of all caesarean sections, a third each. Notably, prelabour caesarean section of primigravid women or 
Table. 2 Relative size and caesarean delivery rates in Brazil using 10- group classification, 2011-2017

\begin{tabular}{|c|c|c|c|c|c|}
\hline $\begin{array}{l}\text { Robson } \\
\text { Group }\end{array}$ & Group definition & $\begin{array}{l}\text { Proportion } \\
\text { of } \\
\text { pregnancies } \\
\%\end{array}$ & $\begin{array}{l}\text { Caesarean } \\
\text { section } \\
\text { rate } \\
\%\end{array}$ & $\begin{array}{l}\text { Contribution of } \\
\text { caesarean section to } \\
\text { overall deliveries } \\
\%\end{array}$ & $\begin{array}{l}\text { WHO } \\
\text { recommended } \\
\text { caesarean rates } \\
\%\end{array}$ \\
\hline 1 & $\begin{array}{l}\text { Nulliparous women with a single cephalic pregnancy, } \geq 37 \text { weeks } \\
\text { gestation in spontaneous labour }\end{array}$ & 16.1 & 43.8 & 7.1 & $<10 \%$ \\
\hline 2 & $\begin{array}{l}\text { Nulliparous women with a single cephalic pregnancy, } \geq 37 \text { weeks } \\
\text { gestation who had labour induced or were delivered by CS } \\
\text { before labour }\end{array}$ & 17.2 & 67.6 & 11.6 & $20-35 \%$ \\
\hline $2 \mathrm{a}$ & Labour induced & 7.32 & 24 & 1.8 & - \\
\hline $2 b$ & Pre-labour CS & 9.86 & 100 & 9.9 & - \\
\hline 3 & $\begin{array}{l}\text { Multiparous women without a previous uterine scar, with a single } \\
\text { cephalic pregnancy, > } 37 \text { weeks gestation in spontaneous labour }\end{array}$ & 18.6 & 17.5 & 3.3 & $<3 \%$ \\
\hline 4 & $\begin{array}{l}\text { Multiparous women without a previous CS, with a single cephalic } \\
\text { pregnancy, } \geq 37 \text { weeks gestation who had labour induced or } \\
\text { were delivered by CS before labour }\end{array}$ & 11.2 & 42.3 & 4.7 & $15 \%$ \\
\hline $4 a$ & Labour induced & 7.21 & 10.3 & 0.7 & - \\
\hline $4 b$ & Pre-labour CS & 4.01 & 100 & 4 & - \\
\hline 5 & $\begin{array}{l}\text { All multiparous women with at least one previous CS, with a } \\
\text { single cephalic pregnancy, } \geq 37 \text { weeks gestation }\end{array}$ & 21.7 & 84.9 & 18.4 & $50-60 \%$ \\
\hline 6 & All nulliparous women with a single breech pregnancy & 1.38 & 89.4 & 1.2 & - \\
\hline 7 & $\begin{array}{l}\text { All multiparous women with a single breech pregnancy including } \\
\text { women with previous CS }\end{array}$ & 1.86 & 84.4 & 1.6 & - \\
\hline 8 & $\begin{array}{l}\text { All women with multiple pregnancies including women with } \\
\text { previous CS }\end{array}$ & 2 & 82 & 1.7 & $60 \%$ \\
\hline 9 & $\begin{array}{l}\text { All women with a single pregnancy with a transverse or oblique } \\
\text { lie, including women with previous } C S(s)\end{array}$ & 0.22 & 96.8 & 0.2 & - \\
\hline 10 & $\begin{array}{l}\text { All women with a single cephalic pregnancy }<37 \text { weeks } \\
\text { gestation, including women with previous CS }\end{array}$ & 9.7 & 48.8 & 4.8 & $30 \%$ \\
\hline
\end{tabular}

multigravida without previous section (2b and $4 \mathrm{~b}$ ) accounted for $25.3 \%$ of all caesarean sections ( Table 2 ).

In general, women who live in municipalities with a higher HDI were more likely to deliver by caesarean section; the most considerable difference in the caesarean section rates between very high and low categories was observed in groups 8 and 10 (Fig. 1). This trend was apparent across all Robson groups, except for group 9 where rates of caesarean section were uniformly close to $100 \%$ irrespective of HDI group.

The general Brazilian caesarean section rate remained stable during the study period $(\beta=0.33 ; \mathrm{p}=0.178)$. Analyses of time-trends by Robson group showed that the caesarean section rate increased in groups 5 and $8(\beta=$ $0.87 ; \mathrm{p}<0.01 ; \beta=0.05 ; \mathrm{p}=0.016$ respectively) and decreased in groups 2,49 and $10(\beta=-0.73 ; p<0.01 ; \beta=-$ $0.27 ; \mathrm{p}<0.01 ; \beta=-0.02 ; \mathrm{p}=0.006 ; \beta=-0.17 ; \mathrm{p}=0.013)$. In the remaining groups, the rates did not change significantly over the years.

A group of 5,036,430 (24.6\%) women could not be classified because of missing or contradictory data, However, the percentage of missing data dropped annually, from $34 \%$ to 2011 to $8.3 \%$ in 2017). We identified
95,472 inconsistent records, most of them $(91,333)$ reported live births or stillbirth/abortion and no previous pregnancy.

\section{Discussion}

In Brazil, caesarean section rates remained stable in the period from 2011 to 2017, always showing very high levels by international standards. The actions implemented in the country to stimulate vaginal delivery could have been effective in containing this increase, but not in reducing it [16]. Our analyses of Robson groups show stable temporal trends and patterns that can be used to characterise practice and suggest improvement.

Robson groups can be separated into those where caesarean section might be absolutely or strongly indicated (Groups 6 to 10) and those with a less strong indication (Groups 1-4). The caesarean section rates in every Robson group are higher than suggested by the WHO Robson guideline, except in group 9 where the recommendation and practice is $100 \%$. Even groups with seemingly favourable conditions for vaginal delivery, such as women with a singleton, term, cephalic 


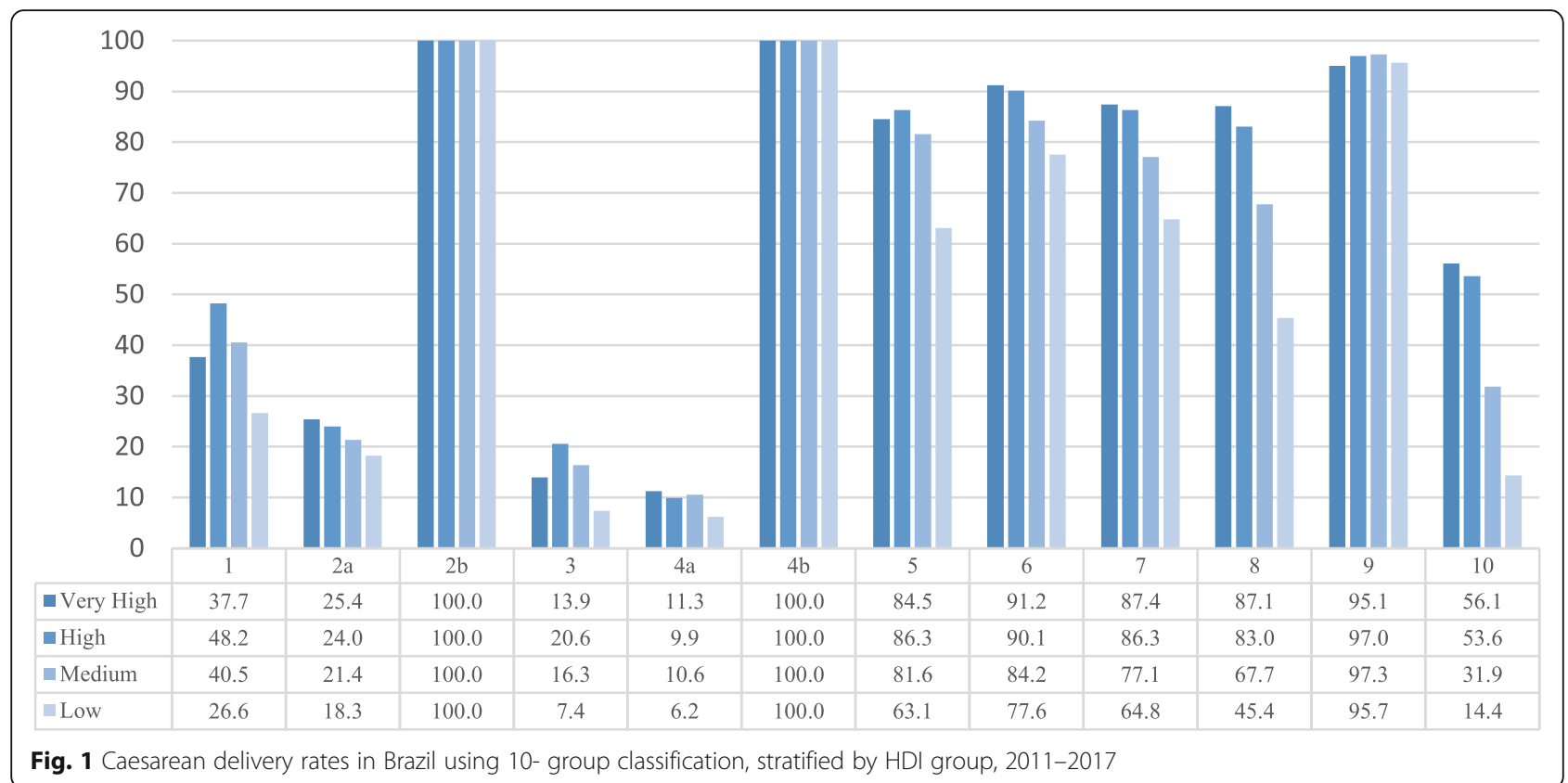

pregnancy, and no previous caesarean (1-4), had an average caesarean rate of higher than $40 \%$.

For Group 5 (previous caesarean section), rates of 50 $60 \%$ would be appropriate, according to WHO standards, however, we see a rate of $84.9 \%$. Because of high historical rates of caesarean section, nearly a quarter of births are to women who are in Group 5. Given the rarity of vaginal birth after caesarean section (VBAC) this group will continue to drive high levels into the future. In groups 6, 7 and 9 the rates are 89.4, 84.4 and $96.8 \%$ respectively, which is appropriate given guidelines on caesarean section for abnormal lie. In Group 8, one should usually expect a rate of around $60 \%$ but we see $82 \%$. For Group 10, usually around $30 \%$, we see $48.8 \%$.

In terms of the relative distribution of the Brazilian obstetric population within Robson groups, the results were similar to those in previous literature. Primigravid women with a single cephalic pregnancy accounted for $1 / 3$ of the obstetric population, and similar findings have been found in France (38.2\%) [17], Canada (39.7\%) [18] and Sri Lanka (38.1\%) [13]. However, prelabour caesarean in Groups $2 \mathrm{~b}$ and $4 \mathrm{~b}$ accounted for $25 \%$ of the overall caesarean rate, a meaningfully higher rate than observed in other settings, such as the USA [19] and Peru [20] where this group accounts for less than $10 \%$. The Robson classification does not include information on indication for caesarean section. Therefore, it is not possible to know if the prelabour caesarean section occurred due to medical indication. However, it is plausible to speculate that in part, these groups had a caesarean delivery for reasons of medical or maternal preference.
Women in spontaneous labour (Group 1 and 3) were more likely to deliver by caesarean section than those with induced labour (Group 2a 4a). One explanation for these findings could be that some of the women in Groups 1 and 3 may have been misclassified and could potentially belong to another group with a higher risk of caesarean delivery or maybe some of them had an intervention carried out without any clear medical indication. This is because maternal request or the physician's preference have consistently been identified as a cause for growing rates of caesarean sections in recent decades [21-23] and this is a common practice in Brazil [24].

Similar findings were previously found for the group of patients with a previous caesarean section in countries such as the USA [19] and in the previous study conducted in Brazil [7]. There is a common misconception in Brazil that after a caesarean section, the following delivery must be a caesarean section, especially in the private sector, where repeated caesarean sections can be higher than $97 \%$. Previous studies have shown that in the public sector, these rates can be much lower among eligible women (52.2\%), and our data showed that in municipalities with lower HDI, it can be around $65 \%$ [25]. However, there is a lack of studies on the effects of the mode of delivery among women with a previous uterine scar. Although some studies have shown that an anterior caesarean section seems to be an important risk factor for the occurrence of placental accretism in later pregnancy, which leads to severe postpartum hemorrhage and maternal death from this cause [26], the evidence available in the literature is controversial. Maternal morbidity and mortality were lower following 
VBAC compared with repeated caesareans in a study performed in China [27] but the opposite was seen among Canadian women [28].

Group 10, premature births, accounted for more than $8 \%$ of caesarean section, slightly higher than that observed in the USA[19]. The rate of caesarean section in this group was also higher than observed in other countries, such as the USA [19], Palestine [29] and Sri Lanka [13].

However, these results were not homogenous in the entire country. There was a notable difference in caesarean rates with varying local socioeconomic conditions. This is demonstrated in the municipalities with the lowest HDI index where there were lower caesarean section rates than in wealthier places. Similar results have been seen in the Robson classification for a multicountry dataset to explore caesarean section trends by HDI [30]. This is even seen for abnormal lie where the recommendations for caesarean section are strong, suggesting women in more deprived areas may be getting less appropriate care.

\section{Strengths}

To our knowledge, this study is the most extensive investigation into caesarean section deliveries in Brazil. The results of this study were similar to the large cohort "Birth in Brazil" however, our study used live birth records (administrative data) of all births in Brazil and "Birth in Brazil" used interviews with a random large sample of women. This is an indication of the quality of the data used in the present study. The use of HDI enables the monitoring of the rate of caesareans and early recognition of any changes in rates of caesareans on a smaller and more homogeneous scale.

\section{Limitations}

The main limitation is the lack of data for some of the core variables used to classify women into one of the Robson groups. The proportion of missing data occurred disproportionately by mode of delivery; it was more frequent among women who delivered by caesarean section, therefore this is a potential source of bias. However, the proportion of missing data decreased over time, suggesting the data quality has been improving since the form was enhanced (2011). SINASC-Brazil was previously shown to underreport information on some core variables needed to classify women into one of the Robson categories, such as gestational age. There is also evidence that the quality of the information has great spatial heterogeneity [31]. Another limitation is that the caesarean section rates in Group 9 were lower than $100 \%$, as recommended by WHO [5], and this could indicate either poor data quality or poor quality of care.

\section{Conclusions}

Brazil is a country with one of the world's highest caesarean section rates. This nationwide population-based study provides the evidence needed to take steps towards improving the provision of clinically indicated caesarean sections. Our results suggest that among higher socioeconomic groups, a caesarean section is undertaken for a high proportion of women with a clinical indication, however, they are also commonly carried out without a clear clinical indication. Among lower socioeconomic groups, caesarean section rates were lower even when clinically indicated, suggesting sub-optimal access to surgical care.

\section{Abbreviations}

SINASC: Live Birth Information System; CIDACS: Centre for Data and Knowledge Integration for Health; HDI: Human Development Index

\section{Acknowledgements}

The authors would like to thank the CIDACS data processing team for all the intense work.

\section{Authors' contributions \\ This study was designed by EP and OC. CB and EP carried the data analyses. $L S, M C, M T, M I, L G, M B$ contributed to study interpretation. All authors revised the manuscript and approved the final version.}

\section{Funding}

CIDACS received core support from Health Surveillance Secretary, Ministry of Health, Brazil; Fundação de Amparo à Pesquisa do Estado da Bahia (FAPESB); Wellcome Trust (Grant number 202912 / Z / 16 / Z); ESP is funded by the Wellcome Trust (grant number 213589/Z/18/Z). However, the funder of this study had no role in the study design, data collection, data analysis, data interpretation, or writing of the report.

\section{Availability of data and materials}

The data that support the findings of this study are available on request from the CIDACS/ FIOCRUZ, and ethical approval. The data are not publicly available due to restrictions as they contain information that could compromise the privacy of research participants.

\section{Declarations}

Ethics approval and consent to participate

For several years, CIDACS has established a partnership with the Brazilian Ministry of Health to hold, link, curate, and use data for research. CIDACS maintains a linkage system for social and health-related data, following all ethical, legal, privacy, and confidentiality requirements. Ethical approval was obtained from the Federal University of Bahia's Institute of Public Health Ethics Committee (CAAE registration number: 18022319.4.0000.5030), and patient consent was not required as the study used only de-identified registrybased secondary data.

\section{Consent for publication \\ Not applicable.}

\section{Competing interests}

The authors declare that they have no competing interests.

\section{Author details}

${ }^{1}$ Faculty of Epidemiology and Population Health, London School of Hygiene and Tropical Medicine, London, United Kingdom. ${ }^{2}$ Centro de Integração de Dados e Conhecimentos para Saúde, Fiocruz, Salvador, Bahia, Brazil. ${ }^{3}$ Institute of Collective Health, Federal University of Bahia - Salvador (BA), Salvador, Brazil. 
Received: 22 September 2020 Accepted: 18 August 2021

Published online: 30 August 2021

\section{References}

1. Betrán AP, et al. Rates of caesarean section: Analysis of global, regional and national estimates. Paediatr Perinat Epidemiol. 2007. doi:https://doi.org/1 0.1111/j.1365-3016.2007.00786.x.

2. Gibbons $L$, et al. Inequities in the use of cesarean section deliveries in the world. Am J Obstet Gynecol. 2012. doi:https://doi.org/10.1016/j.ajog.2012.02. 026.

3. Betran AP, et al. What is the optimal rate of caesarean section at population level? A systematic review of ecologic studies. Reproductive Health. 2015. doi:https://doi.org/10.1186/s12978-015-0043-6.

4. Sandall J, et al. Short-term and long-term effects of caesarean section on the health of women and children. The Lancet. 2018. doi:https://doi.org/1 0.1016/S0140-6736(18)31930-5.

5. Goleman D, Boyatzis, Mckee R, A. Robson Classification, Implementation manual. Journal of Chemical Information and Modeling (2019). doi:https://doi. org/10.1017/CBO9781107415324.004.

6. Betrán AP, Vindevoghel N, Souza JP, Gülmezoglu AM, Torloni MR. A systematic review of the Robson classification for caesarean section: What works, doesn't work and how to improve it. PLoS ONE. 2014. doi:https://doi. org/10.1371/journal.pone.0097769.

7. Nakamura-Pereira M, et al. Use of Robson classification to assess cesarean section rate in Brazil: The role of source of payment for childbirth. Reprod Health. 2016. doi:https://doi.org/10.1186/s12978-016-0228-7.

8. Brunherotti MAA, Prado MF, Martinez EZ. Spatial distribution of Robson 10group classification system and poverty in southern and southeastern Brazil. Int J Gynecol Obstet. 2019. doi:https://doi.org/10.1002/ijgo.12831.

9. Bolognani CV, De Sousa Moreira Reis LB, Dias A. \& De Mattos Paranhos Calderon, I. Robson 10-groups classification system to access C-section in two public hospitals of the Federal District/Brazil. PLoS One. 2018. doi: https://doi.org/10.1371/journal.pone.0192997.

10. Oliveira MM, de, et al. Avaliação do Sistema de Informações sobre Nascidos Vivos. Brasil, 2006 a 2010. Epidemiol e Serviços Saúde. 2015;24:629-40.

11. Brazil, Miistry of Health. Manual de instruções para o preenchimento da declaração de nascido vivo. Fundação Nacional de Saúde Brasília; 2001.

12. Brazil. Sao Paulo. States Health Secretary. Manual de Preenchimento da Declaração de Nascido Vivo Prefeito do Municípiode São Paulo. 1-24 (2011).

13. Senanayake $\mathrm{H}$, et al. Implementation of the WHO manual for Robson classification: An example from Sri Lanka using a local database for developing quality improvement recommendations. BMJ Open. 2019. doi: https://doi.org/10.1136/bmjopen-2018-027317.

14. Brazil. IBGE. (Brazilian Institute of Geography and Statistics). https://ww2. ibge.gov.br/english/ (2018).

15. REGRESSION ANALYSIS BY EXAMPLE, THIRD EDITION CHAPTER 8. THE PROBLEM OF CORRELATED ERRORS I STATA TEXTBOOK EXAMPLES.

16. Occhi GM, de Lamare Franco Netto T, Neri MA, Rodrigues EAB. \& de Lourdes Vieira Fernandes, A. Strategic measures to reduce the caesarean section rate in Brazil. The Lancet. 2018. doi:https://doi.org/10.1016/S01406736(18)32407-3.

17. Le Ray $C$, et al. Stabilising the caesarean rate: Which target population? BJOG An Int J Obstet Gynaecol. 2015. doi:https://doi.org/10.1111/1471-052 8.13199 .

18. Kelly S, et al. Examining Caesarean Section Rates in Canada Using the Robson Classification System. J Obstet Gynaecol Canada. 2013. doi:https:// doi.org/10.1016/S1701-2163(15)30992-0.

19. Hehir MP, et al. Cesarean delivery in the United States 2005 through 2014: a population-based analysis using the Robson 10-Group Classification System. Am J Obstet Gynecol. 2018. doi:https://doi.org/10.1016/j.ajog.2018.04.012.

20. Tapia V, Betran AP, Gonzales GF. Caesarean section in Peru: Analysis of trends using the Robson classification system. PLoS One. 2016. doi:https:// doi.org/10.1371/journal.pone.0148138

21. Kottmel $\mathrm{A}$, et al. Maternal request: $\mathrm{A}$ reason for rising rates of cesarean section? Arch Gynecol Obstet. 2012. doi:https://doi.org/10.1007/s00404012-2273-y.

22. Young ML, D'Alton ME. Cesarean delivery on maternal request: Maternal and neonatal complications. Curr Opin Obstet Gynecol. 2008. doi:https://doi. org/10.1097/GCO.0b013e328317a293.
23. Potter JE, Hopkins K, Faúndes A, Perpétuo I. Women's autonomy and scheduled cesarean sections in Brazil: A cautionary tale. Birth. 2008. doi: https://doi.org/10.1111/j.1523-536X.2007.00209.x.

24. Carlotto K, Marmitt LP, Cesar JA. On-demand cesarean section: assessing trends and socioeconomic disparities. Rev Saude Publica. 2020;54:01.

25. Nakamura-Pereira M, Esteves-Pereira AP, Gama SGN, Leal M. Elective repeat cesarean delivery in women eligible for trial of labor in Brazil. Int J Gynecol Obstet. 2018;143:351-9.

26. Silver RM, Branch DW. Placenta accreta spectrum. N Engl J Med. 2018. doi: https://doi.org/10.1056/NEJMcp1709324.

27. Mu Y, et al. Prior caesarean section and likelihood of vaginal birth, 20122016, China. Bull. World Health Organ. 96, (2018).

28. Joseph KS, et al Mode of delivery after a previous cesarean birth, and associated maternal and neonatal morbidity. CMAJ (2018) doi:https://doi. org/10.1503/cmaj.170371.

29. Zimmo MW, et al. Caesarean section in Palestine using the Robson Ten Group Classification System: A population-based birth cohort study. BMJ Open. 2018. doi:https://doi.org/10.1136/bmjopen-2018-022875.

30. Vogel JP, et al. Use of the robson classification to assess caesarean section trends in 21 countries: A secondary analysis of two WHO multicountry surveys. Lancet Glob Heal. 2015. doi:https://doi.org/10.1016/S2214-109X(1 5)70094-X.

31. Szwarcwald CL, et al. Avaliação das informações do Sistema de Informações sobre Nascidos Vivos (SINASC), Brasil. Cad. Saude Publica 35, (2019).

\section{Publisher's Note}

Springer Nature remains neutral with regard to jurisdictional claims in published maps and institutional affiliations.
Ready to submit your research? Choose BMC and benefit from:

- fast, convenient online submission

- thorough peer review by experienced researchers in your field

- rapid publication on acceptance

- support for research data, including large and complex data types

- gold Open Access which fosters wider collaboration and increased citations

- maximum visibility for your research: over $100 \mathrm{M}$ website views per year

At BMC, research is always in progress.

Learn more biomedcentral.com/submissions 